American Journal of Economics and Business Administration 3 (3): 430-438, 2011

ISSN 1945-5488

(C) 2011 Science Publications

\title{
Implementation and Methods of Project Learning in Quantity Surveying Firms: Barriers, Enablers and Success Factors
}

\author{
Hamzah Abdul-Rahman, Ali Mohammed Alashwal and Zatil Hidayah Jamaludin \\ Department of Quantity Surveying, Faculty of Built Environment, \\ University of Malaya, 50603 Kuala Lumpur, Malaysia
}

\begin{abstract}
Problem statement: Learning from project is vital for organizations to achieve competition and to survive in a dynamic environment. However, learning is not an easy task because there is no specific way for learning from projects. Besides, the practice of project learning and transfer knowledge to the firm's level is still vague, specifically in the construction milieu. Approach: A questionnaire survey was conducted targeted quantity surveying firms in Malaysia, attempted to identify methods of learning from projects and implement this approach successfully. Interviews with experts in construction projects were conducted to expand and validate the results of the survey. Results: The findings indicated that on-the-job training is the preferable method to learn from construction project in quantity surveying firms. In addition, top management support and employee participants are the main enablers/barriers of project learning implementation. While, top management support found to be the main key success factor of project learning implementation. Conclusion/Recommendations: Determining barriers and enablers of learning showed how construction organization could implement learning from project successfully. This adds a practical tool of promoting learning in the field of organizational learning in construction. Results can be replicated in different industries to observe the disparity in each setting.
\end{abstract}

Key words: Construction, knowledge management, project learning practice, QS firms

\section{INTRODUCTION}

Construction project's success depends on good management and on construction players' awareness and commitment of different problems that may arise during the course of the project. Project learning plays a vital role in adding-value to construction project (Abdul-Rahman et al., 2008; Love and Edwards, 2004; Ismail et al., 2010) and guarantee competitive advantages of the firms (Landaeta, 2008; Awwad and Almahamid, 2008). However, learning is not an easy task and knowledge and experience of previous construction projects are usually in a tacit form (Schindler and Eppler, 2003). Maqsood et al. (2006) affirm that construction firms and personnel prefer to carry out their project management tasks based on their past experience rather than following a textbook approach or established analytical approaches. Consequently, knowledge of construction organizations would probably be lost after the experts leave the company. Organizations rarely learn from their past projects because they do not have a mechanism to capture and store all the information and knowledge in place (Williams, 2008).

Experience and knowledge accumulation in project is very important, especially in construction projects, where every project has at least one area of risk and uncertainty that may danger the objectives of the project (Storm and Savelsbergh, 2005). Breakdown of communication between project team may danger knowledge sharing and contribute to risk escalating in construction industry (Hassim et al., 2009). Project learning practice is believed to be a significant aspect to deal with the previous problems. Therefore, the current paper investigates the development of project learning approach to help project-based organizations maintain their good performance. Specifically, this paper intends to identify the learning methods of construction quantity surveying firms and to determine barriers, enablers and success factors of implementing this approach. Quantity surveying firms were chosen for this investigation because their operation depends mostly on individuals with high tacit knowledge form. Besides, there is a lack of investigation on these kinds

Corresponding Author: Hamzah Abdul-Rahman, Department of Quantity Surveying, Faculty of Built Environment, University of Malaya, 50603 Kuala Lumpur, Malaysia Tel: +6037967-3202 
of firms, specifically in Malaysia, though their role in developing the construction industry is vital.

Knowledge management in QS profession: Knowledge management is a systematic approach to help information and knowledge emerge and flow to the right people at the right time to create value (Marwick, 2001). Companies who want to leverage the asset must approach knowledge management to accomplish the mission and vision of the companies (Tiwana, 1999). Knowledge is the main contributor to the surveyor's portfolio. As a result, effective knowledge management skills can help to improve their expertise (Davis et al., 2007).

Efficient knowledge management of quantity surveying firms depends on the capability of the individual to plan, manage, operate, monitor and control for making the decision (Lobermans, 2002). Though utilizing of knowledge management is good but it does not guarantee success. There are some potential difficulties in QS profession related to knowledge management include for instance unwillingness to change the current operating system, unwillingness of employees to share their knowledge and misunderstanding and difficulty to evaluate knowledge management (Davis et al., 2007).

Knowledge management techniques can be divided into a codification and personalization approach (Davis et al., 2007). Codification approach describes how the system can help to capture the experience and knowledge of experts within the QS firms before the team members leave (Davis et al., 2007). While, the personalization approaches express that the knowledge, experience and skills can be captured via interviewing, protocol analysis, questionnaire surveys and observation and simulation. Personalization approach is applied in construction firms because it facilitates the communications of everyone in the organization, so they can easily transfer and share their knowledge and information in the arena of projects (Suman and Psunder, 2008).

Project learning and learning methods: Project learning practice can be defined as a set of actions that the project teams use to create and share knowledge within project (intra-project) and across projects (interproject) (Kotnour, 2000; Kotnour and Proctor, 1996). Intra-project learning can be defined as the acquisition approach and use of knowledge and experience within the same project (Gieskes and Broeke, 2000). It focuses on tasks within a single project and supports the delivery of a successful project by identifying problems and solving them during the project life cycle (Kotnour and Vergopia, 2007). On the other hand, inter-project learning refers to the transfer of knowledge and experience from one project to other projects within the same time frame or to different projects over a period of time. It involves combining and sharing of lessons learned across projects to develop a new knowledge (Kotnour and Kurstedt, 2000).

Project learning reviews can be classified into two main methods (Schindler and Eppler, 2003): Processbased methods and documentation-based methods. Figure 1 illustrates the two methods. Process-based methods are gathering of lessons learned from concluded projects and explaining the relevant steps and sequences of a project's time line. It consists of two methods: Post-project appraisal and after action review. Post Project Appraisal (PPA) represents a special type of project review that includes a strong learning element. For the After Action Review method (AAR), it can help team members learn immediately from errors and successes. Documentation-based method is more about learning from the project's experience and the storage of contents within the organization. This method consists of micro articles, learning histories and recall. Micro articles are introduced to secure the experience after completion of a project. It is the process to transfer the experience to explicit form via the authorizing of small articles. Learning history is a written story which consists of the main events of a project arranged in a chronological order (Schindler and Eppler, 2003). Finally, recall staffs' impending of lessons learned directly using an internet browser (Maqsood et al., 2006). This method facilitates and automates the capture and the retrieval of the lessons learned.

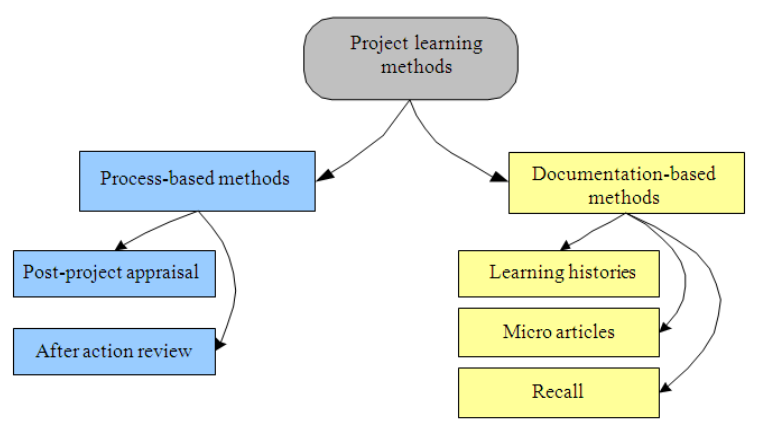

Fig. 1:Methods of recording knowledge and learning from projects (developed after Schindler and Eppler, 2003) 
Literature on project learning uncovered other methods of learning generally. According to Law and Chuah (2004) there are some tools that would improve team communication and consequently facilitate learning, namely, dialogue; learning histories; leadership styles and management techniques and the role of organizational goals and strategies. In construction, approaches used to facilitate learning including formal face-to-face interaction, periodic meetings, documentation learning and problem solving methods (Abdul-Rahman et al., 2008).

Project learning and the success factors: Davis, Watson and Man (2007) purported that the most critical success factors of implementing project learning in quantity surveyor firms are top management support, employee active participation, application of IT systems and creating knowledge space. Rahman (2004) affirms that the head of department is the key player for implementing learning process successfully. He or she should be the major player in promoting project learning in the organization. Furthermore, the head of department (middle-manager) would encourage the creating and the sharing of tacit knowledge through the process of internalization and socialization or a combination of both (Nonaka, 1999).

Continuous project learning through regular reviews is one of the key success factors of project learning (Schindler and Eppler, 2003). There are several advantages of the periodic review during the course of a project, for instance, the experience is more up-to-date and the lessons learned can be recalled easily (Cooper et al., 2002). Generally, establishing new roles and tasks for projects can help to support learning activities (Schindler and Eppler, 2003). In this regard, role of the debriefer is crucial to facilitate and manage the debriefing of knowledge and learning. The debriefer identifies the critical key learning areas and must be responsible for the validation of the context information. Lastly, to ensure the successful implementation of project learning method, complexity and type of projects shall be considered (Knauseder et al., 2007).

Barriers of project learning implementation: Majority of previous studies express that the main barriers for a firm to implement project learning are unwillingness of the team members to share their knowledge, lack of time and understanding of knowledge management and the difficulty to locate, capture, generalize and store knowledge (Davis et al., 2007; Law and Chuah, 2004). Others, for example Rahman (2004), asserts that barriers always occur in motivating employees, difficulty in identifying knowledge management related roles and responsibilities, level of technology, ability of existing IT systems, obsolete data, information overload and data overload. It is expected that the construction industry will lose a large portion of its skilled and knowledge workforce (Teerajetgul and Charoenngam, 2006) and this will, in turn, lead to the loss of important sources of knowledge and experience.

Construction firms, usually, conduct more than one project at the same time. Hence, individuals face difficulties to learn due to limitation of time (Law and Chuah, 2004). Although construction is a highly informative and knowledge intensive industry, but the long life cycle of projects and the moving from one project to another could make it difficult for firms and individuals to cumulate knowledge over time (Fong and Chu, 2006). This may lead also to the knowledgeforgetting phenomenon (Lam et al., 2001). To overcome this problem, Kotnour and Vergopia (2007) suggested including learning during the whole life cycle of the project.

\section{MATERIALS AND METHODS}

A questionnaire survey was employed to gather data to respond to the objectives of this research. The questionnaire survey was used to present a collective view of project learning methods and implementation. Then, 7 interviews were conducted to confirm and expand the results of the questionnaire. The target respondents of this research are Principal, Senior Quantity Surveyors and Quantity Surveyors in quantity surveying firms. All the selected respondents were ensured to have between 4-20 years of experience in construction and had managed more than five projects during those years. The questionnaire was approached to quantity surveyor firms, in Kuala Lumpur and Selangor, Malaysia, which had been selected based on their experience and their orientation towards project learning. A total of 318 questionnaires were sent out. The valid returned questionnaires were 58 that represent a response rate of $18 \%$.

Respondents and background of firms: Most of the respondents of the questionnaire were top managers, directors or senior quantity surveyors. This gave the results higher accuracy and reliability. The highest percentage of the respondents, about $45 \%$, is of those who have more than 20 years of experiences. More than $25 \%$ of the respondents were having 10-20 years experience. Table 1 illustrates the respondents and companies' background. 


\section{RESULTS}

The questionnaire survey: In answering the first objective of this study, the results show that on-the-job training is the most common method of project learning practice. Referring to Table 2, there are 14 different project learning methods, which were identified from literature. On-the-job training, the highest mean of 4.04, is the most preferable technique implemented by the QS firms.

The second objective of this study is to identify the success factor of implementing the project learning. The results affirm the findings of Davis et al. (2007); Rahman (2004) and Schindler and Eppler (2003). The factors requires top management support. Other factors of the success of project learning implementation include employees' participation and commitment; application of IT systems; institutionalised lessons learned and culture changes (Table 3).

From the survey, there are many barriers that hamper project learning practice. Top management can be considered as a critical factor that drawbacks the implementation of project learning. Top management has dual role where it can encourage or discourage individuals to develop a knowledge sharing culture in the organizations. Managers face the problem of promoting project learning practices (Law and Chuah, 2004) and encourage the staff to transfer their tacit knowledge to explicit knowledge (refer to Table 4 for other factors).

This investigation uncovered the factors to overcome these barriers. Table 5 shows these factors, which include: top management support, application of IT systems, employee participants, changes and organization. Top management has a role in increasing the awareness of staff about the benefits of project successful implementation of project learning practice

learning. Top management also can support project teams to change their behaviour in responding with learning.

Table 1: Questionnaire respondents and companies' background

\begin{tabular}{llcr}
\hline & Category breakdown & Frequency & $(\%)$ \\
\hline \multirow{2}{*}{$\begin{array}{l}\text { Respondents' } \\
\text { designation }\end{array}$} & Director & & \\
& senior quantity & 28 & 48.27 \\
& Surveyor & 19 & 32.76 \\
& Quantity surveyor & 7 & 12.07 \\
& Assistant quantity & 4 & 6.90 \\
& Surveyor & & \\
& Less than 5 years & 7 & 12.10 \\
Respondents' & 5-10 years & 10 & 17.20 \\
experience & 10-20 years & 15 & 25.90 \\
& More than 20 years & 26 & 44.80 \\
& Private individuals & & \\
Company status & Corporate & 35 & 60.30 \\
& Organizations & 23 & 39.70 \\
Company & Less than 5 years & 4 & 6.90 \\
experienced & 5-10 years & 7 & 12.10 \\
& 10-20 years & 26 & 44.80 \\
& More than 20 years & 21 & 36.20 \\
\hline
\end{tabular}

Table 2: Project learning methods of quantity surveying firms

\begin{tabular}{llllllr}
\hline Learning method & $\mathrm{N}$ & Min. & Max. & Mean & Std. D. & Rank \\
\hline Imitation & 47 & 2 & 5 & 3.55 & 0.829 & 9 \\
Informal interaction & 56 & 3 & 5 & 3.73 & 0.674 & 6 \\
Creation of new roles & 41 & 2 & 5 & 3.29 & 0.716 & \\
Periodic meeting & 53 & 2 & 5 & 3.98 & 0.772 & 3 \\
Debriefing & 50 & 2 & 5 & 3.94 & 0.767 & 4 \\
Problem solving techniques & 48 & 2 & 5 & 4.00 & 0.772 & 2 \\
Learn by helping people & 53 & 2 & 5 & 3.70 & 0.774 & 7 \\
Simulation & 29 & 2 & 5 & 3.48 & 0.785 & \\
On the job training & 52 & 2 & 5 & 4.04 & 0.740 & 1 \\
Job variation & 51 & 1 & 5 & 3.57 & 0.806 & 8 \\
Trial and error & 41 & 1 & 5 & 3.22 & 0.936 & 11 \\
Extrapolate past events & 51 & 1 & 5 & 3.55 & 0.783 & 9 \\
Internet information & 56 & 1 & 5 & 3.36 & 0.883 & \\
searching & 10 & & & & & \\
Documentation learning & 58 & 2 & 5 & 3.81 & 0.736 & 5 \\
\hline
\end{tabular}

Table 3: The success factors of project learning implementation

\begin{tabular}{|c|c|c|c|c|c|c|}
\hline Success factors & $\mathrm{N}$ & Min. & Max. & Mean & Std. deviation & Rank \\
\hline Head of department should promote the benefits of lesson learnt & 58 & 2 & 5.00 & 4.310 & 0.754 & 4 \\
\hline $\begin{array}{l}\text { Head of department should encourage the sharing of } \\
\text { knowledge and experiences among the staffs }\end{array}$ & 58 & 3 & 5.00 & 4.470 & 0.706 & 1 \\
\hline $\begin{array}{l}\text { Head of department encourage the transfer of explicit } \\
\text { knowledge to explicit knowledge }\end{array}$ & 58 & 3 & 5.00 & 4.260 & 0.664 & 5 \\
\hline $\begin{array}{l}\text { Develop a database for storing a project info, } \\
\text { project cost, duration of the projects and others }\end{array}$ & 58 & 2 & 5.00 & 4.380 & 0.768 & 3 \\
\hline $\begin{array}{l}\text { Using the mail, telephone, facsimile, intranet, video conferencing } \\
\text { and telephone conferencing for communications, exchanging the ideas }\end{array}$ & 58 & 2 & 5.00 & 3.900 & 0.831 & 10 \\
\hline $\begin{array}{l}\text { Application of project management software } \\
\text { for learning and sharing the knowledge }\end{array}$ & 58 & 1 & 5.00 & 3.340 & 0.828 & 12 \\
\hline Disciplines & 58 & 3 & 5.00 & 4.450 & 0.626 & 2 \\
\hline Have an incentives training to develop a knowledge sharing among the staffs & 58 & 1 & 5.00 & 4.000 & 0.858 & 8 \\
\hline $\begin{array}{l}\text { Try to motivate the team members to share the } 58 \\
\text { knowledge and experience from the previous projects }\end{array}$ & 1 & 5 & 4.26 & 0.890 & 5.000 & \\
\hline Knowledge and experience will be managed efficiently & 58 & 2 & 5.00 & 4.140 & 0.736 & 7 \\
\hline Need to have changes in the culture of the organization & 58 & 2 & 5.00 & 3.840 & 0.768 & 11 \\
\hline Changes in the development of management, learning, motivation and others & 58 & 3 & 5.00 & 3.910 & 0.657 & 9 \\
\hline
\end{tabular}


Am. J. of Economics and Business Administration 3 (3): 430-438 2011

Table 4: Barriers of implementing project learning

\begin{tabular}{|c|c|c|c|c|c|c|}
\hline Barriers of project learning & $\mathrm{N}$ & Min. & Max. & Mean & Std. deviation & Rank \\
\hline $\begin{array}{l}\text { Managers do not promote the project } \\
\text { learning systems in the organizations }\end{array}$ & 58 & 1 & 5.00 & 2.790 & 1.348 & 10 \\
\hline $\begin{array}{l}\text { Managers do not encourage the staff to transfer the } \\
\text { tacit knowledge in the staff minds to the explicit knowledge }\end{array}$ & 58 & 1 & 5.00 & 2.790 & 1.321 & 10 \\
\hline $\begin{array}{l}\text { Managers face the problem to motivate the } \\
\text { staffs to share the knowledge }\end{array}$ & 58 & 1 & 5.00 & 3.210 & 1.181 & 3 \\
\hline Unwillingness to share knowledge among the staffs & 58 & 1 & 5.00 & 3.160 & 1.089 & 5 \\
\hline $\begin{array}{l}\text { Unwillingness involve in the incentive training, } \\
\text { studyshop and others to develop a knowledge sharing }\end{array}$ & 58 & 1 & 5.00 & 3.030 & 1.042 & 6 \\
\hline $\begin{array}{l}\text { Lack of discussion, meeting, exchange the } \\
\text { ideas within the staffs }\end{array}$ & 58 & 1 & 5.00 & 3.240 & 1.144 & 2 \\
\hline $\begin{array}{l}\text { Lack of incentives training to the employees to } \\
\text { develop a knowledge sharing }\end{array}$ & 58 & 1 & 5.00 & 3.000 & 1.009 & 7 \\
\hline Time consuming & 58 & 1 & 5.00 & 3.170 & 1.172 & 4 \\
\hline $\begin{array}{l}\text { Lack of discipline and lack of resources on the } \\
\text { project learning practices }\end{array}$ & 58 & 1 & 5.00 & 3.280 & 0.988 & 1 \\
\hline $\begin{array}{l}\text { Lack of database to store the knowledge } 58 \\
\text { from the previous projects }\end{array}$ & 1 & 5 & 2.98 & 1.116 & 8.000 & \\
\hline $\begin{array}{l}\text { Lack of software to gather the knowledge and } \\
\text { experience from the previous project such as } \\
\text { Wessex Programmed, Master Bill Programme and Build Soft }\end{array}$ & 58 & 1 & 5.00 & 2.910 & 1.128 & 9 \\
\hline
\end{tabular}

Table 5: Factors of overcoming the barriers while implementing project learning practices

\begin{tabular}{|c|c|c|c|c|c|c|}
\hline Overcoming the barriers & $\mathrm{N}$ & Min. & $\operatorname{Max}$ & Mean & Std. deviation & Rank \\
\hline Top management should encourage the knowledge sharing among staffs & 58 & 2 & 5 & 4.33 & 0.758 & 1 \\
\hline $\begin{array}{l}\text { Top management should provide explanation to staffs about } \\
\text { the benefits they will get when project is implemented }\end{array}$ & 58 & 2 & 5 & 4.22 & 0.773 & 2 \\
\hline $\begin{array}{l}\text { Develop more software to gather the knowledge and } \\
\text { experiences from the past projects }\end{array}$ & 58 & 1 & 5 & 3.69 & 0.922 & 11 \\
\hline $\begin{array}{l}\text { Provide more telecommunication tools such as telephone, facsimile, } \\
\text { video conferencing and telephone conferencing for intranet, } \\
\text { communications, exchanging of ideas }\end{array}$ & 58 & 1 & 5 & 3.74 & 1.001 & 10 \\
\hline Employees willingness to learn a software to store their knowledge & 58 & 1 & 5 & 3.97 & 0.917 & 8 \\
\hline Discipline & 58 & 2 & 5 & 4.16 & 0.894 & 4 \\
\hline Employees accept changes in managing their knowledge & 58 & 2 & 5 & 4.16 & 0.875 & 4 \\
\hline Need to have changes in the culture of the organization & 58 & 2 & 5 & 3.95 & 0.782 & 9 \\
\hline Employees must willing to adapt changes & 58 & 2 & 5 & 4.14 & 0.826 & 6 \\
\hline Need more discussion and exchange the ideas among the staffs & 58 & 2 & 5 & 4.21 & 0.720 & 3 \\
\hline $\begin{array}{l}\text { Implement an appropriate training programme } \\
\text { developing a knowledge sharing }\end{array}$ & 58 & 2 & 5 & 4.09 & 0.823 & 7 \\
\hline
\end{tabular}

Table 6: Reliability of the survey

\begin{tabular}{lll}
\hline Set of variables & $\begin{array}{l}\text { Cronbach's } \\
\text { alpha }\end{array}$ & $\begin{array}{l}\text { Items' } \\
\text { No. }\end{array}$ \\
\hline $\begin{array}{l}\text { Project learning method of the QS firms } \\
\text { Success factor of implementing }\end{array}$ & 0.921 & 14 \\
project learning practices & 0.834 & 12 \\
Barriers of implementing project learning & 0.908 & 11 \\
Recommendation to overcome the barriers & 0.869 & 11 \\
\hline
\end{tabular}

The interviews: The study conducted 7 interviews with top management and QS individuals work in construction projects. Generally, all the interviewees agreed with the results of the questionnaire survey. Though they concur that the problem-solving technique is an important method of project learning, but one of the interviewees has her own standpoint that:

"The problem-solving technique is not effective to implement especially during the pre-construction stage unless the problem solving techniques will apply with informal interaction and debriefing",

Reliability of the survey: The questionnaire survey was found to be reliable as the results of the reliability test were satisfied. The Cronbach's Alpha value is higher than 0.8 for all constructs. Table 6 shows the set of variables used in the questionnaire and the cumulative value of each of the variable.

\section{DISCUSSION}

On-the-job training, according to the survey, is the most preferred way of learning in QS firms this because it seems to be the easiest, applicable way compared with others. Team members may feel that this way is easier for learning and developing a knowledge-sharing spirit. The second common way of learning, according to the survey, is problem-solving techniques. In this 
method, a brainstorming session of team members used to share and create knowledge. By using this method, the experience of QS can be written in a short note or "a Micro-article" (Schindler and Eppler, 2003). The other team members can refer to this note as guidance for their upcoming projects. Another common method of learning is the periodic meeting. There are many types of meetings such as meeting minutes, ad hoc meeting, weekly meeting and monthly meeting. Main issues occur during the construction stage can be highlighted and recorded during the periodic meetings. Other employees can use this information as a reference to deal with similar situations. On the other hand, debriefing is another preferred method of learning. The depriefer is in-charge to make sure that the relative information and knowledge are gathered, stored and retrieved appropriately. In this method, the individuals will be questioned in detail regarding the study that has been executed in terms of: failure, success, mistakes and innovation. This method could be categorized under the documentation learning method (Schindler and Eppler, 2003). This method is important because every generated lesson-learned needs to be documented properly.

Besides, this method would reduce the problems related to knowledge sharing and learning process during the construction stage. According to the results of the survey, trial and error is rarely used during the pre-construction stage. It is, probably, due to the high risk associated with this method.

Team members must be willing to learn and share their knowledge and experience. In facilitating the application of project learning practice, the respondents emphasized on the application of information communication technology tools. Whereas, the study of Newell et al. (2002) emphasized that ICT alone is not a key enabler of this process; but it will be useful for cross project learning.

According to an interviewee from a private company, extrapolate of past events can also be an appropriate project learning method during the preconstruction stage. That is because the QS's experience is necessary to handle the upcoming projects and avoid repeating the same mistakes and increase the productivity of the projects. However, three of interviewees expressed that all of the methods are applicable but their utilization depends on the projects' environment. From QS perspectives, information searching can be described as a method of learning. On the other hand, informal interaction can ease the communication, especially at the site. This affirms the suggestions in the literature about including the social relationship for knowledge sharing and learning, besides the utilization of ICT tools (Newell et al., 2002;
Fong and Chu, 2006; Styhre et al., 2006). In contrast, one of the respondents stated that:

"It is good if the company has applied the usage of information technology because even though there is a lack of discussion [face-toface interaction], team members can still transfer their tacit knowledge to the explicit knowledge in the database. Indeed, all the staff can refer to their information from the database and learn something new".

According to the interviewees, study culture is very important to develop the project learning practice. The team members must have an initiative to accept change. The results of the interviews also highlighted some barriers of project learning implementation include the lack of discipline and resources to learn. Besides, the team members always behave in a more enclosed manner and they think that they protect their rights of keeping knowledge to themselves. The respondents' feedback from the questionnaire survey showed that the most critical barriers of project learning practices are top management, employee participants, organization and lack of application of IT systems, lack of discipline and lack of resources on the project learning practices. In spite of the barriers, all the interviewees have not considered top management as a barrier. They see management as a positive aspect that aids individuals all the time and not as a drawback. The most common way to overcome the barrier is the role of top management to support sharing knowledge. Besides, managers have the duty of introducing new roles as for instance the debriefer.

One of the respondents argued that lacking of Information Technology (IT) systems is not indicated as barriers for lessons learned sharing. It is because explicit knowledge can still be kept in simple and available computer software. On the other hand, the respondents from a private sector have different perspectives where they expressed that the application of IT system is not the best way to overcome the barriers. It is due to the time constraint and unwillingness of the team members to share their knowledge.

Top management support is an important factor in assessing ways of overcoming the barriers. However, this factor alone is not enough as the employees' discipline is necessary in developing a learning process. Moreover, the discipline of every team member must consider employees' willingness to accept the changes while managing the learning process. Providing appropriate training programs, which focus on developing knowledge sharing, can be a good way to overcome the barriers. A summary of the interviewees' feedback and other opinions on project learning practice is shown in Table 7. 
Am. J. of Economics and Business Administration 3 (3): 430-438 2011

\begin{tabular}{|c|c|c|c|c|}
\hline Respondent & Success factor & $\begin{array}{l}\text { Appropriate method } \\
\text { for project learning }\end{array}$ & Barriers & $\begin{array}{l}\text { Solution on how to } \\
\text { overcome the barriers }\end{array}$ \\
\hline $\begin{array}{l}\text { Vice presidents } \\
\text { Quantity surveyor }\end{array}$ & $\begin{array}{l}\text { - Top management } \\
\text { support }\end{array}$ & $\begin{array}{l}\text { - Formal interaction } \\
\text {-Documentation learning }\end{array}$ & $\begin{array}{l}\text {-Time consuming } \\
\text {-Time consuming }\end{array}$ & -Top management support \\
\hline Chief assistant director & $\begin{array}{l}\text { - Institutional lesson learn } \\
\text { - Organization } \\
\text { - Changes }\end{array}$ & $\begin{array}{l}\text {-Formal interaction } \\
\text {-Debriefing }\end{array}$ & $\begin{array}{l}\text {-Unwillingness team members } \\
\text { to share the knowledge } \\
\text {-Lack of discussion } \\
\text {-Application of IT Systems } \\
\text {-Discipline }\end{array}$ & $\begin{array}{l}\text {-Need the changes } \\
\text {-Top management support } \\
\text {-Organization must be improved }\end{array}$ \\
\hline Chief assistant director & $\begin{array}{l}\text {-Top management support } \\
\text {-Employee participants }\end{array}$ & $\begin{array}{l}\text {-On the job training } \\
\text {-Formal interaction }\end{array}$ & $\begin{array}{l}\text {-Culture changes } \\
\text {-Disciplines }\end{array}$ & $\begin{array}{l}\text {-Top management support } \\
\text {-Application of IT systems }\end{array}$ \\
\hline Assistant director & $\begin{array}{l}\text {-Top management support } \\
\text {-Application of IT }\end{array}$ & $\begin{array}{l}\text {-Depend on the study } \\
\text { environment }\end{array}$ & $\begin{array}{l}\text {-Unwillingness team members } \\
\text { to share the knowledge } \\
\text { - Time Consuming }\end{array}$ & $\begin{array}{l}\text {-Top management support } \\
\text {-Employee participants }\end{array}$ \\
\hline Assistant director & $\begin{array}{l}\text {-Top management support } \\
\text {-Employee participants }\end{array}$ & $\begin{array}{l}\text {-On the job training } \\
\text {-Documentation learning }\end{array}$ & $\begin{array}{l}\text { - Lack of resources } \\
\text { regarding project learning } \\
\text {-Employee Participants } \\
\text {-Periodic Meeting } \\
\text {-Lack of discipline }\end{array}$ & $\begin{array}{l}\text {-Top management support } \\
\text {-Develop more software's to gather the } \\
\text { knowledge from past project }\end{array}$ \\
\hline Senior quantity surveyor & $\begin{array}{l}\text {-Top management support } \\
\text {-Institutionalized lesson learns }\end{array}$ & $\begin{array}{l}\text {-Imitation } \\
\text {-Face to face interaction } \\
\text {-On the job training } \\
\text {-Job Variation } \\
\text {-Documentation Learning }\end{array}$ & $\begin{array}{l}\text {-Unwillingness to } \\
\text { share knowledge }\end{array}$ & $\begin{array}{l}\text {-Need more discussion } \\
\text {-Top management should encourage } \\
\text { the knowledge sharing }\end{array}$ \\
\hline Quantity surveyor & $\begin{array}{l}\text {-Top management support } \\
\text {-Application of IT systems } \\
\text {-Extrapolate past events }\end{array}$ & $\begin{array}{l}\text { - Informal interaction } \\
\text {-On the job training }\end{array}$ & -Lack of IT application & -Produce the standard procedure \\
\hline
\end{tabular}

\section{CONCLUSION}

To sum up, the top five project learning methods used in quantity surveying firms are: on-the-job training, problem solving techniques, periodic meetings, debriefing and documentation learning. As a way to facilitate learning, some of the respondents affirmed the importance of having a portal to store the knowledge and experience of the QS experts.

Based on the survey, the highest success factor is the top management support. Indeed, managers have the ability to influence and assist the staff to implement learning successfully. However, the role of employees and their commitment towards learning cannot be denied. Without employees discipline and participation, top management support is not valuable.

The results of the survey indicated that there are many barriers face the project learning practice. The respondents' feedback showed that the most critical barriers are: Top management, employee participation and lack of application of IT systems, lack of discipline and lack of resources on the project learning. The results of the interviews showed other barriers as time constraint, staff unwilling to change and share their knowledge. However, managers can play important role in motivating the team members to overcome the difficulties of implementation of project learning. Top management play a positive role to motivate staff and promote benefits of implementing project learning practice. The systematic discussion among the expertise during the frequent meetings may give better solutions to overcome the barriers. In dealing with the problem of lack of time to learn, it is recommended here that quantity surveying firms have to develop a standard procedure of knowledge sharing and learning as a practice in projects. Furthermore, the team members shall have the initiative to accept new changes in the organization to enhance their performance.

This research shall be extended to include other professionals and stakeholders in construction. On the other hand, identifying the advantages of project learning implementation empirically is recommended for future research. Furthermore, managing the lessons learned from previous project and apply them in new projects still one of the challenges that faces the QS firms.

Lastly, achieving high-performance construction project teams and competitive firms require the successful implementation of project learning, whereby each individual in the firm has the awareness and commitment to accomplish and to learn.

\section{REFERENCES}

Abdul-Rahman, H., I.A. Yahya, M.A. Berawi and W.W. Low, 2008. Conceptual delay mitigation model using a project learning approach in practice. Construct. Manage. Econ., 26: 15-27. DOI: $10.1080 / 01446190701744350$ 
Awwad, A.S. and S.M. Almahamid, 2008. The link between modification flexibility and organizational objectives: An empirical study on jordanian manufacturing companies. J. Soc. Sci., 4: 299-307. DOI: $10.3844 /$ jssp.2008.299.307

Cooper, K.G., J.M. Lyneis and B.J. Bryant, 2002. Learning to learn, from past to future. Int. J. Project Manage., 20: 213-219. DOI: 10.1016/S02637863(01)00071-0

Davis, R., P. Watson and C.H. Man, 2007. Knowledge management for the quantity surveying profession. Strategic Integration of Surveying Services, FIG Studying Week, Hong Kong SAR, China, pp: 1-16.

Fong, P.S. and L. Chu, 2006. Exploratory study of knowledge sharing in contracting companies: A sociotechnical perspective. J. Construct. Eng. Manage., 132: 928-939. DOI: 10.1061/(ASCE)0733-9364(2006)132:9(928)

Gieskes, J.F.B. and A.M.T. Broeke, 2000. Infrastructure under construction: Continuous improvement and learning in projects. J. Manufact. Technol. Manage., 11: 188-198. DOI: 10.1108/09576060010320425

Hassim, S., M.S. Jaafar and S.A.A.H Sazalli, 2009. The Contractor perception towers industrialized building system risk in construction projects in Malaysia. Am. J. Applied Sci., 6: 937-942. DOI: 10.3844/ajassp.2009.937.942

Ismail, A., R. Aminzadeh, A. Aram and I. Arshad, 2010. Value engineering application in highway projects. Am. J. Eng. Applied Sci., 3: 699-703. DOI: 10.3844/ajeassp.2010.699.703

Knauseder, I., P.R. Josephson and A. Styhre, 2007. Learning approaches for housing, service and infrastructure project organizations. Construct. Manage. Econ., 25: 857-867. DOI: $10.1080 / 01446190601164121$

Kotnour, T. and C. Vergopia, 2007. A framework and findings for learning based project reviews. Proceedings of the Portland International Center of Management of Engineering and Technology, Aug. 5-9, Portland, Oregon, USA., pp: 2074-2079. DOI: 10.1109/PICMET.2007.4349538

Kotnour, T. and H.A. Kurstedt, 2000. Understanding the lessons-learned process. Int. J. Cognitive Ergon., 4: 311-330. DOI: 10.1207/S15327566IJCE0404_3

Kotnour, T. and M. Proctor, 1996. Processes and tools to support knowledge management in a virtual organization. Proceedings of the International Conference on Engineering and Technology Management, Aug. 18-20, Vancouver, BC, Canada, pp: 247-252. DOI: 10.1109/IEMC.1996.547823
Kotnour, T., 2000. Organizational learning practices in the project management environment. Int. J. Qual. Reliab. Manage., 17: 393-406. DOI: $10.1108 / 02656710010298418$

Lam, K.C., D. Lee and T. Hu, 2001. Understanding the effect of the learning-forgetting phenomenon to duration of projects construction. Int. J. Project Manage., 19: 411-420. DOI: 10.1016/S02637863(00)00025-9

Landaeta, R., 2008. Evaluating benefits and challenges of knowledge transfer across projects. Eng. Manage. J., 20: 29-38.

Law, K.M.Y. and K.B. Chuah, 2004. Project-based action learning as learning approach in learning organisation: The theory and framework. Team Perform. Manage., 10: 178-186. DOI: $10.1108 / 13527590410569904$

Lobermans, J., 2002. Synergizing the learning organization and knowledge management. J. Knowl. Manage., 6: 285-294. DOI: $10.1108 / 13673270210434386$

Love, P. and D. Edwards, 2004. Determinants of rework in building construction projects. Eng., Construct. Arch. Manage., 11: 259-274. DOI: 10.1108/09699980410547612

Maqsood, T.A., A. Finegan and D. Walker, 2006. Applying project histories and project learning through knowledge management in an Australian construction company. Learn. Org., 13: 80-95. DOI: 10.1108/09696470610639149

Marwick, A.D., 2001. Knowledge management technology. IBM Syst. J., 40: 814-830. DOI: 10.1147/sj.404.0814

Newell, S., H. Scarbrough, J. Swan, M. Robertson and R.D. Galliers, 2002. The importance of process knowledge for cross project learning: Evidence from a UK Hospital. Proceedings of the 35th Hawaii International Conference on System Sciences, Jan. 07-10, Big Island, Hawaii, pp: 109109.

Nonaka, I., 1999. The Dynamics of Knowledge Creation. In: The Knowledge Advantage: 14 Visionaries Define Marketplace Success in New Economy, Ruggles, R. and D. Holtshouse (Eds.). Oxford Ernst and Young LLP, UK., pp: 64-87. ISB: 13: 9781841120676

Rahman, A.B., 2004. Knowledge management strategy in Malaysia. Proceedings of the Knowledge Management International Conference (KMICe), Feb. 14-15, Penang, Malaysia. 
Schindler, M. and M.J. Eppler, 2003. Harvesting project knowledge: A review of project learning methods and success factors. Int. J. Project Manage., 21: 219-228. DOI: 10.1016/S02637863(02)00096-0

Storm, P. and C. Savelsbergh, 2005. Lack of Managerial learning as a potential cause of project failure. pp: 1-17.

Styhre, A., P.E. Josephson and I. Knauseder, Organization learning in non-writing communities. Manage. Learn., 37: 83-100. DOI: $10.1177 / 1350507606060983$

Suman, N. and M. Psunder, 2008. Mobile computing changing the traditional ways of organizing the construction company. Am. J. Applied Sci., 5: 4247. DOI: 10.3844/ajassp.2008.42.47
Teerajetgul, W. and C. Charoenngam, 2006. Factors inducing knowledge creation: Empirical evidence from Thai construction projects. Eng., Construct. Arch. Manage., 13: 584-99. DOI: 10.1108/09699980610712382

Tiwana, A., 1999. Knowledge Management Toolkit: The Practical Techniques for Building a Knowledge Management System. 1st Edn., Upper Saddle River, Prentice Hall, N.J, ISBN: 10: 0130128538, pp: 640.

Williams, T., 2008. How do organizations learn lesson from projects-and do they?. IEEE Trans. Eng. Manage., 55: 248-266. DOI: 10.1109/TEM.2007.912920 